\title{
Effect of hydration with Ringer's solution submitted to magnetic field in an experimental model of hepatic ischemia-reperfusion injury in rats
}

\section{Efeito da hidratação com solução de Ringer submetida a campo magnético em modelo experimental de lesão de isquemia-reperfusão hepática em ratos}

Juliana Mendonça Freire ${ }^{1}$, Jeovana Pinheiro Fernandes Souza ${ }^{1}$, Ítalo Medeiros de Azevedo ${ }^{2}$, Fabio Medeiros de Azevedo ${ }^{3}$, Artur da Silva Carriço ${ }^{4}$, Aldo Cunha Medeiros ${ }^{5}$

1. Graduate student, Medical School, Federal University of Rio Grande do Norte (UFRN), NatalRN, Brazil.

2. Fellow PhD degree, Postgraduate Program in Health Sciences, UFRN, Natal-RN, Brazil.

3. Pathologist, Pathology center of University Hospital Onofre Lopes, UFRN, Natal-RN, Brazil.

4. PhD, Full Professor, Department Physics, UFRN, Natal-RN, Brazil.

5. PhD, Full Professor, Chairman, Nucleus of Experimental Surgery, UFRN, Natal-RN, Brazil.

Study performed at Department of Surgery, Federal University of Rio Grande do Norte (UFRN), Brazil. Program of Scientific Initiation

Financial support: CNPq.

Conflict of interest: None.

Correspondence address: Department of Surgery, Federal University of Rio Grande do Norte, at Ave. Nilo Peçanha 620, Natal, RN, Brazil. E-mail: cirurgex.ufrn@gmail.com Submitted: september 4; accepted after revision, October 16, 2018.

\section{ABSTRACT}

Purpose: To evaluate the effect of hydration with Ringer's solution submitted to magnetic field in experimental model of hepatic ischemia/reperfusion in rats. Methods: Wistar rats weighing $389.58 \pm 46.88 \mathrm{~g}$ were randomly allocated into 2 groups: control group $(n=6)$ - Hepatic ischemia/reperfusion and hydration with Ringer's solution; and test group $(n=6)$ - Hepatic ischemia/reperfusion and hydration with Ringer submitted to magnetic field of $20 \mathrm{mT}$ during 2 hours. After anesthesia with ketamine $70 \mathrm{mg} / \mathrm{kg}$ and xylazine $7 \mathrm{mg} / \mathrm{kg}$ i.p., the animals were weighed and operated by aseptic technique. The ischemia of the median and left liver lobes was induced for 30 minutes using a vascular clip. Then, i.v. hydration with $3 \mathrm{ml}$ of Ringer in the control group, and $3 \mathrm{ml}$ of magnetized Ringer's solution in the test group. After 24 hours, blood sample and fragment of the left liver lobe were collected for the determination of AST, ALT, ALP and albumin levels, and histopathological examination. Results: There was no significant difference in comparison of the rats weight loss, biochemical measurements and histopathological scores between the groups ( $p>0.05)$. Conclusion: The hydration with Ringer's solution submitted to magnetic field after hepatic ischemia/reperfusion in rats did not alter liver 
Effect of hydration with Ringer's solution submitted to magnetic field in an experimental model of hepatic ischemia-reperfusion injury in rats

Freire JM, et al

function tests neither histopathological scores, comparing with the control group.

Keywords: Ischemia. Reperfusion. Liver. Magnetics. Fluid therapy.

\section{RESUMO}

Objetivo: Avaliar o efeito da hidratação com solução de Ringer submetido à ação de campo magnético em modelo experimental de isquemia e reperfusão hepática em ratos. Métodos: Ratos Wistar pesando 389,58 $\pm 46,88 \mathrm{~g}$ foram distribuídos em 2 grupos: grupo controle $(n=6)$ - Isquemia/reperfusão hepática e hidratação com solução de Ringer; e grupo teste $(n=6)$ - Isquemia/reperfusão hepática e hidratação com Ringer submetido a campo magnético de $20 \mathrm{mT}$ por 2 horas. Após anestesia com cetamina 70 $\mathrm{mg} / \mathrm{kg}$ de peso e xilazina $7 \mathrm{mg} / \mathrm{Kg}$ i.p., os animais foram pesados e operados com técnica asséptica. A isquemia dos lobos mediano e esquerdo do fígado foi realizada por 30 minutos, usando clipe vascular. Em seguida, hidratação i.v.com $3 \mathrm{ml}$ de Ringer no grupo controle, e $3 \mathrm{ml}$ de Ringer submetido a campo magnético no grupo teste. Após 24 horas, sangue total e biópsia do lobo esquerdo do fígado foram colhidos para dosagem de AST, ALT, fosfatase alcalina e albumina, e exame histopatológico respectivamente. Resultados: Não houve diferença significante entre os grupos na comparação da perda de peso, das dosagens bioquímicas e dos escores histopatológicos ( $p>0,05)$. Conclusão: A hidratação com solução de Ringer submetida à ação de campo magnético após isquemia/reperfusão hepática em ratos não alterou as provas de função hepática nem os escores histopatológicos, comparando-se com o grupo controle.

Descritores: Isquemia. Reperfusão. Fígado. Magnetismo. Fluidoterapia.

\section{INTRODUCTION}

Hepatic ischemia/reperfusion injury $(I / R)$ is involved in several surgical procedures such as transplantation, trauma and surgical resection ${ }^{1,2}$. This process can lead to several deleterious modifications resulting from the production of reactive oxygen species (ROS), cytokines, adhesion molecules and vasoactive agents (endothelin and thromboxane-A2), combined with a decrease of cytoprotective agents including nitric oxide and prostacyclins $s^{3,4}$. As a consequence, a process of cell death occurs due to necrosis and cellular apoptosis reaching distant organs such as kidneys, lungs and pancreas, as well as the liver itself ${ }^{5,6}$. 
Effect of hydration with Ringer's solution submitted to magnetic field in an experimental model of hepatic ischemia-reperfusion injury in rats

Freire JM, et al

Large amount of evidences illustrate that magnetic fields (MF) can affect ROS. However, there is no consensus about the exact effects. This is due the several reported experimental results, which are affected by different parameters such as MF characteristics, biological samples examined, as well as experimental configuration ${ }^{7}$.

In parallel, some studies have shown that magnetized water increases permeability across membranes ${ }^{8,9}$ and the magnetic field can induce intracellular fluids to activate cellular enzymes and accelerate biochemical reactions in body tissues ${ }^{10}$. Water submitted to magnetic field has higher $\mathrm{pH}$ and electrical conductivity compared to drinking water ${ }^{11}$. Magnetic water treatment alters physical and chemical characteristics by converting the kinetic energy of the ions into electrical energy. Thus, the electrolytes become activated and can easily bind to other organic compounds ${ }^{12}$. These activated electrolytes are rapidly absorbed and promote the biological activation of tissues, cells and enzymes on metabolism ${ }^{13}$. For this reason, their use is supposed to activate antioxidant enzymes and reduce DNA damage, but these effects and mechanisms are still poorly understood.

Ischemia/reperfusion injury is one of the most investigated aspects in experimental surgery, being extremely relevant in procedures involving hepatic trauma ${ }^{14}$. To attenuate the injurys and prevent organ loss, several strategies have been studied, such as surgical interventions, pharmacological agents and gene therapy ${ }^{5}$. Thus, it is necessary to understand the metabolic processes resulting from hepatic ischemia and reperfusion and the relation with hydration with magnetized Ringer's solution, in order to minimize intra and postoperative complications. The objective of the present study was to evaluate the effect of hydration with Ringer's solution submitted to magnetic field in experimental model of hepatic ischemia and reperfusion in rats.

\section{METHODS}

The experiment was done using twelve Wistar rats (Rattus norvegicus) weighing $389.58 \pm 46.88 \mathrm{~g}$ obtained from the Health Center Facility of the Federal University of Rio Grande do Norte (UFRN). Initially the animals went through a period of 7 days of acclimatization at the Nucleus of Experimental Surgery of UFRN, with ad libitum access to water and food for rats (Prevence ${ }^{\circledR}$ ). 
Effect of hydration with Ringer's solution submitted to magnetic field in an experimental model of hepatic ischemia-reperfusion injury in rats

Freire JM, et al

The rats were randomly allocated to two experimental groups: control group ( $\mathrm{n}$ =6) - Hepatic ischemia/reperfusion and hydration with Ringer's solution; and test group $(n=6)$ - Hepatic ischemia/reperfusion and hydration with Ringer's solution submitted to magnetic field of $20 \mathrm{mT}$ during 2 hours. After twelve hours of fasting, the rats were anesthetized with ketamine $70 \mathrm{mg} / \mathrm{kg}$ body weight and xylazine $7 \mathrm{mg} / \mathrm{kg}$ i.p. The animals were weighed and operated under aseptic technique described below: trichotomy, antisepsis with $70 \%$ ethanol, median laparotomy of $5 \mathrm{~cm}$ from the xiphoid appendix to access the liver. Hepatic ischemia was induced for 30 minutes by occlusion of blood vessels supplying the median and left liver lobes using a vascular clip. During the entire period of ischemia, the abdomen was temporarily closed by suturing. After removal of the vascular clip, blood flow was restored. Then the animal was slowly hydrated with $3 \mathrm{~mL}$ of Ringer's solution in the control group, and $3 \mathrm{~mL}$ of magnetized Ringer's solution in the test group using a catheter № 24 and surgical microscope (DF Vasconcelos, São Paulo, Brazil) by surgical dissection of left femoral vein. All animals were observed during 24 hours in individual cages with water and rodent feed ad libitum.

The Ringer's solution was exposed to magnetic field of $20 \mathrm{mT}$ intensity produced through 6 magnets in an adapted model (Figure 1). The solution was exposed to MF during 2 hours immediately before the surgical procedure and venous infusion.

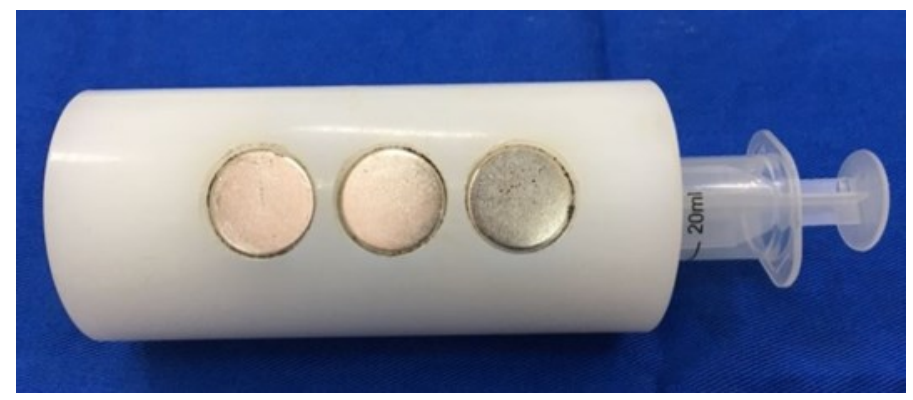

Figure 1 -Ringer's solution exposure to magnetic field of 20mT intensity using 06 magnets (adapted model).

The hepatic injury was measured by serum levels of aspartate aminotransferase (AST), alanine aminotransferase (ALT), albumin and alkaline phosphatase (ALP) in blood sample obtained by cardiac puncture in anesthetized animals. 
Effect of hydration with Ringer's solution submitted to magnetic field in an experimental model of hepatic ischemia-reperfusion injury in rats

Freire $J M$, et al

Histopathological examination of left hepatic lobe was done after the animal's euthanasia with thiopental $100 \mathrm{mg} / \mathrm{kg}$ i.p. The tissue samples were sent to Pathology Laboratory. The fresh liver tissue was sectioned into $5 \mathrm{~mm}$ thickness fragments and washed in running water allowing fast and uniform action of the fixative solution. The samples were fixed in $10 \%$ buffered formaldehyde for a maximum period of 48 hours, and then processed for 18 hours in an automated tissue processor using Leica TP 1020 equipment. Before the paraffin inclusion, the processed fragments were cut with punchtype equipment, in the gauge of $4 \mathrm{~mm}$, for standardization of samples. Fixed liver samples were stained by Hematoxylin/Eosin (H/E) for morphological analysis in microscope (Olympus CX41, Tóquio, Japan). Morphological criteria were used to assess histopathological hepatic $\mathrm{I} / \mathrm{R}$ injury severity: neutrophil infiltration, sinusoidal congestion, vacuolization, cytoplasmic edema and degree of necrosis. The findings were graduated individually on a scale of 0 to 4 by experienced pathologist.

The quantitative variables normality was evaluated using the Shapiro Wilk test and Kolmogorov-Smirnov test. A comparison was made between groups using Student's t-test on independent samples and the non-parametric Mann-Whitney test for the samples that did not present normality. The analysis was performed using SPSS 20.0 software considering the significant differences at $p$-value $<0.05$.

\section{RESULTS}

All animals survived the experiment. One control group animal was excluded from the study because the results were discrepant within the group. The results regarding the body mass loss in the 24 hours post procedure, AST, ALT, ALP and albumin serum levels are summarized in the Table 1. No significant difference was observed comparing the groups $(p>0.05)$. 
Effect of hydration with Ringer's solution submitted to magnetic field in an experimental model of hepatic ischemia-reperfusion injury in rats

Freire JM, et al

Table 1 - Statistical analysis of data according to the group.

\begin{tabular}{lccc}
\hline \multicolumn{1}{c}{ Variable } & \multicolumn{2}{c}{ Group } & \\
& $(\mathrm{N}=5)$ & $\begin{array}{c}\text { Test } \\
(\mathrm{N}=6)\end{array}$ & -value $^{1}$ \\
\hline Body mass loss (\%) & $4.8 \pm 2.76$ & $4.1 \pm 1.04$ & 0.573 \\
AST (U/L) & $632.8 \pm 233.61$ & $524 \pm 153.08$ & 0.376 \\
ALT (U/L) & $468.6 \pm 271.35$ & $440.8 \pm 144.93$ & 0.833 \\
ALP (U/L) & $265.2 \pm 45.73$ & $273.5 \pm 55.18$ & 0.795 \\
Albumin (g/L) & $2.4 \pm 0.55$ & $2.5 \pm 0.55$ & $0.752^{2}$ \\
\hline
\end{tabular}

Mean \pm standard deviation. 1 - Student's t-test (P-value <0.05). 2 - Non-parametric MannWhitney test $(\mathrm{P}$-value $<0.05)$.

In both groups were observed histological alterations degrees ranging between them. Sinusoidal congestion, neutrophil infiltration and necrosis were the most frequent alterations (Figure 2). Only 3 samples, one from the control group and two from the test group, did not present any histological lesion degree in the liver. Statistical analysis showed no significant difference between groups (Table 2).
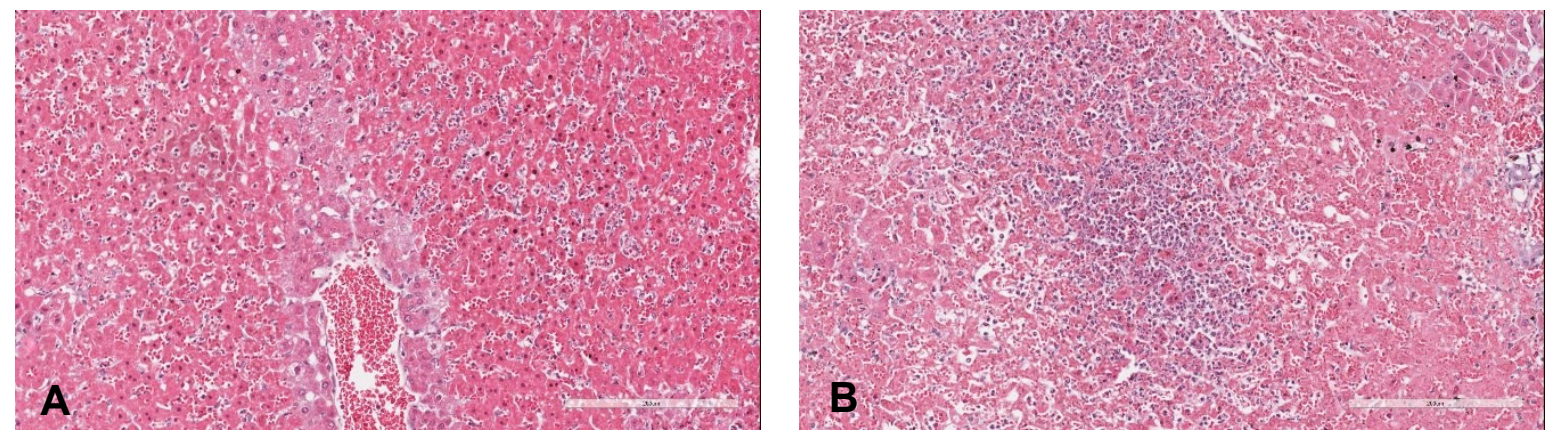

Figure 2 - Morphological analysis of ischemic left hepatic lobe fragment (H/E staining, 20x). Hepatic sinusoidal congestion (A); Tissue necrosis and neutrophil infiltration (B). 
Effect of hydration with Ringer's solution submitted to magnetic field in an experimental model of hepatic ischemia-reperfusion injury in rats

Freire JM, et al

Table 2 - Statistical analysis of histopathological graduation data according to the group.

\begin{tabular}{lccc}
\hline \multicolumn{1}{c}{ Variable } & \multicolumn{2}{c}{ Groups } & \\
& $\begin{array}{c}\text { Control } \\
(\mathrm{N}=5)\end{array}$ & $\begin{array}{c}\text { Test } \\
(\mathrm{N}=6)\end{array}$ & -valor $^{1}$ \\
\hline Neutrophil infiltration & $0.00(1,50)$ & $1.00(1.00)$ & 0.686 \\
Sinusoidal congestion & $1.00(0,50)$ & $1.00(1.00)$ & 0.637 \\
Vacuolization & $0.00(0,50)$ & $0.00(0.00)$ & 0.273 \\
Cytoplasmic edema & $0.00(0,50)$ & $0.00(1.00)$ & 0.273 \\
Necrosis & $0.00(0,50)$ & $1.00(1.00)$ & 0.140 \\
\hline
\end{tabular}

Median (interquartile deviation - Q1-Q3). 1 - Non-parametric Mann-Whitney test (P-value $<0.05)$.

\section{DISCUSSION}

According to the literature, the recommended period of hepatic ischemia ranges from 30 to 100 minutes, with the longer periods related to partial hepatic ischemia with vascular shunts, and shorter periods related to complete ischemia without vascular shunts ${ }^{15}$. Therefore we used 30 minutes as the standard time for the ischemia period.

Biochemical and metabolic events, functional disorders and morphological findings have been associated with the functional alterations observed during I/R due to necrosis and apoptosis involved in cell death ${ }^{5,15-17}$. In the present study, we used the aminotransferases (ALT, AST), ALP and albumin to evaluate the hepatic injury degree. Aspartate aminotransferase and alanine aminotransferase are considered good indicators of hepatocyte cell membrane lesion ${ }^{16}$, so high levels of these enzymes are correlated with the necrosis extent of these cells ${ }^{18}$. The ALT and AST levels mean were higher in the control group, but the difference between the groups was not significant, suggesting that the cell injury was similar.

Alkaline phosphatase is an enzyme found in cholangiocytes, which are present in the bile ducts lining. Therefore, the ALP release occurrence in plasma is related with liver cholangiocyte lesion. In rodents, these cells consist in $3 \%$ of the liver cells ${ }^{18}$. In our test group the ALP mean was slightly higher compared to the control group, but there was no statistical significance between them. Low albumin levels are expected in hepatic 
Effect of hydration with Ringer's solution submitted to magnetic field in an experimental model of hepatic ischemia-reperfusion injury in rats

Freire $J M$, et al

injury, which was evidenced in both groups. In the body mass loss assessment both groups had a reduction, the control group with a slightly larger loss. In both parameters, the statistical analysis was no significant.

The necrotic cells morphology is characterized by increased eosinophilia, cytoplasm vacuoles, cellular edema and membranes ruptures with intracellular contents extravasation, causing inflammation and aggression of adjacent healthy tissues ${ }^{5,15}$. In our study, the necrosis degree was evaluated semi-quantitatively and graded from 0 to 4 in the samples collected after 24 hours of reperfusion. Both groups presented histological lesions in different degrees compatible with hepatic ischemia, such as sinusoidal congestion, cell necrosis, and neutrophil infiltration. Some authors reported different degrees of liver damage ranging according to the time of ischemia/reperfusion, tissue volume, number of cycles, total duration of ischemia ${ }^{2,15,19}$. Freitas et al reported that ischemia times ranging from 10 to 30 minutes, with progressive periods of reperfusion (up to 120 minutes), showed increasing changes in tissue features, suggesting a time-dependent relationship between ischemia/reperfusion and the severity of the hepatic injury ${ }^{15}$.

The electromagnetic fields influence has been studied by some scientists which related the interaction of MF with ion channels, oxidative stress and physical structure of water ${ }^{7,12,20}$ suggesting a better fluidity of the aqueous solution and consequently a potentiation of ischemia process hydration. In our experiment, there was no significant difference between the parameters of each group that indicated the magnetic field influence on the Ringer's solution involving I/R phenomenon.

Because it is a phenomenon involving several mechanisms, influenced by many factors such as duration of ischemia/reperfusion, added to the complexity and recent knowledge about the effects of the magnetic field in the biological processes, further studies are still necessary to elucidate this interaction better of the magnetic field with the biological fluids.

In conclusion, the hydration with Ringer's solution submitted to magnetic field after hepatic ischemia/reperfusion in rats did not alter liver function tests neither histopathological scores, comparing with control. 
Effect of hydration with Ringer's solution submitted to magnetic field in an experimental model of hepatic ischemia-reperfusion injury in rats

Freire JM, et al

\section{REFERÊNCIAS}

1. Lu Z, Lin Y, Peng B, Bao Z, Niu K, Gong J. Hydrogen-Rich Saline Ameliorates Hepatic Ischemia-Reperfusion Injury Through Regulation of Endoplasmic Reticulum Stress and Apoptosis. Dig Dis Sci. 2017; 62: 3479-86.

2. Magyar Z, Varga G, Mester A, Ghanem S, Somogyi V, Tanczos B, Deak A, Bidiga L, Peto $\mathrm{K}$, Nemeth $\mathrm{N}$. Is the early or delayed remote ischemic preconditioning the more effective from a microcirculatory and histological point of view in a rat model of partial liver ischemia-reperfusion? Acta Cir Bras. 2018; 33(7):597-608.

3. Jaeschke H. Molecular mechanisms of hepatic ischemia-reperfusion injury and preconditioning. AJP-Gastroint Liver Physiol. 2003; 284:15-26.

4. Abu-Amara M, Yang SY, Quaglia A, Rowley P, de Mel A, Tapuria N, et al. Nitric oxide is an essential mediator of the protective effects of remote ischaemic preconditioning in a mouse model of liver ischaemia/reperfusion injury. Clin Sci (Lond). 2011; 121(6):257-66.

5. Nakazato PCG, et al. Liver ischemia and reperfusion injury. Pathophysiology and new horizons in preconditioning and therapy. Acta Cir Bras. 2018; 33(8):723-35.

6. Malhi H, Gores GJ, Lemasters JJ. Apoptosis and necrosis in the liver: a tale of two deaths? Hepatology. 2006; 43:S31-S35.

7. Wang H, Zhang X. Magnetic Fields and Reactive Oxygen Species. Int J Mol Sci. 2017; 18:E2175.

8. Gonet B. Influence of constant magnetic fields on certain physiochemical properties of water. Bioelectromagnetics 1985;6:169-75.

9. Lednev VV. Possible mechanism for the influence of weak magnetic fields on biological systems. Bioelectromagnetics 1991;12:71-5.

10. Liboff AR, Cherng S, Jenrow KA, Bull A. Calmodulin-dependent cyclic nucleotide phosphodiesterase activity is altered by $20 \mu \mathrm{T}$ magnetostatic fields. Bioelectromagnetics 2003;24:32-8.

11. Xu YB, Sun SY. Effect of stable weak magnetic field on $\mathrm{Cr}(\mathrm{VI})$ bio-removal in anaerobic SBR system. Biodegradation. 2008;19:455-62.

12. Lee HJ, Jo HR, Jeon EJ, Kang MH. Effect of the magnetized water supplementation on lymphocyte DNA damage in mice treated with diethylnitrosamine. Korean J Nutr. 2010;43:570-7.

13. Ayrapetyan G, Papanyan A, Hayrapetyan H, Ayrapetyan S. Metabolic pathway of magnetized fluid-induced relaxation effects on heart muscle. Bioelectromagnetics. 2005;26: 624-630.

14. Papadopoulos D, Siempis T, Theodorakou E, Tsoulfas G. Hepatic Ischemia and Reperfusion Injury and Trauma: Current Concepts. Arch Trauma Res. 2013;2:63-70.

15. Freitas SH, Doria RGS, Bueno RS, Rocha WB, Filho JRE, Vidane AS, Ambrósio CE. Evaluation of potential changes in liver and lung tissue of rats in an ischemia- 
Effect of hydration with Ringer's solution submitted to magnetic field in an experimental model of hepatic ischemia-reperfusion injury in rats

Freire $J M$, et al

reperfusion injury model (modified Pringle maneuver). PLoS One. 2017;12(6):e0178665.

16. Ferchichi H, Bacha S, Kourda N, Gaies E, Melaouhia S, Lakhal M, Klouz A, Trabelsi S, Salouage I. Animal model of liver ischemia reperfusion: biochemical and histological evaluation. Tunis Med. 2016;94(3):235-43.

17. de Groot $H$, Rauen $U$. Ischemia-reperfusion injury: processes in pathogenetic networks: A rewiew. Transpl Proc. 2007;39:481-95.

18. Knudsen AR, Andersen KJ, Hamilton-Dutoit S, et al. Correlation between liver cell necrosis and circulating alanine amino-transferase after ischaemia/reperfusion injuries in the rat liver. Int J Exp Pathol. 2016;97:133-8.

19. de Lourdes Jorge G, dos Reis Tártaro R, Escanhoela CF, Boin IFSF. Later evaluation of ischemia and reperfusion by the pringle maneuver in Wistar rats, demonstrating that hepatic lesions can be reversible. Transplant Proc. 2017;49(4):898-901.

20. Goychuk I. Sensing Magnetic Fields with Magnetosensitive Ion Channels. Sensors. 2018;18:728-9. 